\title{
Alkaline and Halophilic Protease Production by Bacillus luteus H11 and Its Potential Industrial Applications
}

\author{
Agnieszka Kalwasińska*, \\ Urszula Jankiewicz², Tamás \\ Felföldi ${ }^{3}$, Aleksandra \\ Burkowska-But ${ }^{1}$ and Maria \\ Swiontek Brzezinska'
}

'Department of Environmental Microbiology and Biotechnology, Nicolaus Copernicus University, Lwowska 1, PL-87100 Toruń, Poland ${ }^{2}$ Department of Biochemistry, Warsaw University of Life Sciences, Nowoursynowska 159, PL-02787 Warsaw, Poland

${ }^{3}$ Department of Microbiology, Eötvös Loránd University, Pázmány Péter sétány 1/C, HU-1117 Budapest, Hungary

Received: 4 October 2017 Accepted: 4 September 2018

\section{(1) (8)}

*Corresponding author:

Phone: +48566112521;

Fax: +486114443;

E-mail:kala@umk.pl

ORCID IDs: 0000-0002-2435-567X (Kalwasińska), 0000-0003-2240-6629 (Jankiewicz), 0000-0003-2009-2478 (Felföldi), 0000-0002-7449-4678 (Burkowska-But), 0000-0002-4552-3951 (Swiontek Brzezinska)

\section{SUMMARY}

This paper presents the results of the study on the production of protease by Bacillus luteus $\mathrm{H} 11$ isolated from an alkaline soda lime. B. luteus $\mathrm{H} 11$ was identified as an alkalohalophilic bacterium, and its extracellular serine endoprotease also showed an extreme alkali- and halotolerance. It was remarkably stable in the presence of $\mathrm{NaCl}$ up to $5 \mathrm{M}$. The enzyme was active in a broad range of $\mathrm{pH}$ values and temperatures, with an optimum $\mathrm{pH}$ of 10.5 and a temperature of $45^{\circ} \mathrm{C}$. It had a molecular mass of about $37 \mathrm{kDa}$ and showed activity against azocasein and a synthetic substrate for the subtilisin-like protease, $\mathrm{N}$-succinyl---phenylalanine-p-nitroanilide. The halo-alkaline protease produced by $B$. luteus $\mathrm{H} 11$ seems to be significant from an industrial perspective because of its tolerance towards high salinity and alkalinity as well as its stability against some organic solvents, surfactants and oxidants. These properties make the protease suitable for applications in food, detergent and pharmaceutical industries, and also in environmental bioremediation.

Key words: Bacillus, proteolytic bacteria, alkalohalophiles, serine endoprotease, subtilisins

\section{INTRODUCTION}

A majority of the biocatalysts obtained from microorganisms isolated from soil, water, food, etc. cannot be applied in harsh industrial processes owing to their low osmotic, pH, or temperature tolerance. As a consequence, new environments are explored in the search for new enzymes, and there is increasing interest in enzymes from extremophiles, as they are naturally adapted to extreme environmental conditions $(1,2)$.

Proteases (EC 3.4.21) represent over $65 \%$ of the total industrial enzyme market, of which the vast majority are alkaline proteases (3). These enzymes, showing exceptional activity and stability in the highly alkaline $\mathrm{pH}$, are applied mainly in detergent formulations $(4,5)$. Furthermore, they have various other industrial applications, such as meat tenderization, leather dehairing and tanning, silk degumming, organic synthesis, medical diagnoses, and silver recovery from X-ray films $(6,7)$.

Currently available commercial alkaline proteases, e.g. Alcalase, Savinase, Esperase (Novozymes, Bagsværd, Denmark) or FoodPro subtilisin (Du Pont, Wilmington, NC, USA) used in organic transformations are active at wide ranges of $\mathrm{pH}(7-11.5)$ and temperature (30-80 $\left.{ }^{\circ} \mathrm{C}\right)$. However, the information about their halotolerance is not easily accessible, although it would be extremely useful for the application of the enzyme in a solution with low water activity. Stable by nature and active at high salt concentrations, halophilic and moderately halophilic proteases offer important opportunities in biotechnological applications, such as food processing, biosynthetic processes, soil bioremediation and sewage treatment. Therefore, finding of novel enzymes showing optimal activities at extreme ranges of $\mathrm{pH}$, salt concentration, and temperature is of great importance (8-11). In addition, halophilic microbes can serve as an important source of salt-tolerant genes for the salt-resistant transgenic plants $(12,13)$.

Bacillus species and Bacillus-related genera are often defined as important sources of extracellular proteases $(14,15)$. Most of these enzymes were obtained from moderately halophilic microorganisms, e.g. Bacillus clausii I-52 (16), Bacillus subtilis FP-133 (17), Paenibacillus 
peoriae NRRL BD-62, Paenibacillus polymyxa SCE2 (18), Halobacillus sp. SR5-3 (19), Halobacterium sp. SP1 (1) (20), Virgibacillus sp. SK37 (21), Geomicrobium sp. EMB2 (22), and Halobacillus blutaparonensis M9 (23). However, reports from halophilic proteases are very limited in the literature (24).

An extremely artificial environment of alkaline and saline distillery lime located at the premises of a soda production facility in Janikowo, Poland (East-Central Europe) was investigated for novel strains showing interesting physiological properties, important from a biotechnological perspective (25). The aim of the present research is to develop conditions for the synthesis of proteolytic enzyme produced by the bacterial strain Bacillus luteus $\mathrm{H} 11$ isolated previously. In addition, the purified, halo-alkaline protease from $B$. luteus $\mathrm{H} 11$ was characterized.

\section{MATERIALS AND METHODS}

\section{Medium components, chemicals and equipment}

Medium components: sodium caseinate, glucose, yeast extract, peptone, agar, beef extract, tryptone, fructose, maltose, sucrose and starch were purchased from Biocorp (Warsaw, Poland). Shrimp waste originated from the Krymar (lłowo, Poland) processing facility. Chemicals: $\mathrm{MgSO}_{4} \cdot 7 \mathrm{H}_{2} \mathrm{O}, \mathrm{NaCl}, \mathrm{Na}_{2} \mathrm{CO}_{3}$, $\mathrm{K}_{2} \mathrm{HPO}_{4}, \mathrm{HgCl}_{2}, \mathrm{HCl},\left(\mathrm{NH}_{4}\right)_{2} \mathrm{SO}_{4}$, 2-amino-2-(hydroxymethyl)propane-1,3-diol (Tris), $\mathrm{HCl}, \mathrm{NaOH}, \mathrm{H}_{3} \mathrm{BO}_{3}, \mathrm{H}_{3} \mathrm{PO}_{4}, \mathrm{CH}_{3} \mathrm{COOH}$, metal ions, acetone, butanol, ethanol, methanol, ethylenediaminetetraacetic acid (EDTA) and dimethyl sulfoxide (DMSO) were purchased from Alchem Grupa Sp. z o.o. (Toruń, Poland). Other chemicals: aprotinin, bestatin, diisopropyl phosphorofluoridate (DFP), ethylene-bis(oxyethylenenitrilo)tetraacetic acid tetrasodium (EGTA), E-64, lodoacetamide, Pefabloc ${ }^{\oplus}$, pepstatin, phenylmethylsulfonyl fluoride (PMSF), 1,10-phenantrolin, Natosyl-L-lysine chloromethyl ketone hydrochloride (TLCK), cetyl trimethylammonium bromide (CTAB), sodium dodecyl sulphate (SDS), Triton X-100, Tween 80, urea, $\mathrm{H}_{2} \mathrm{O}_{2}, \mathrm{~N}$-succinyl-Gly-Gly-Phe-p-nitroanilide, $\mathrm{N}$-succinyl-L-phenylalanine-p-nitroanilide, Na-benzoyl-L-arginine 4-nitroanilide hydrochloride, and Z-Gly-Gly-Leu-p-nitroanilide, Superdex 200, Bradford reagent, bovine serum albumin, polyacrylamide and amide black solution were purchased from Sigma-Aldrich (St. Louis, MO, USA). Rotiphorese ${ }^{\circledR}$ NF-Acrylamide/Bis-solution and buffer components were purchased from Carl Roth $\mathrm{GmbH}+\mathrm{Co}$. KG (Karlsruhe, Germany). Britton-Robinson buffer was prepared according to Reynolds et al. (26).

Bacterial cultures were incubated in the Heraeus incubator (ThermoFisher Scientific, Waltham, MA, USA) and shaken in the IKA ${ }^{\circledR}$ KS 260 basic orbital shaker (Ika-Werke, Staufen, Germany). Enzyme reaction mixtures were incubated using the TS-100C thermo-shaker (Biosan, Riga, Latvia). Bacterial cultures/ enzyme reaction mixtures were centrifuged at 6000/10 000×g in the Rotina centrifuge (Hettich, Tuttlingen, Germany). Absorbance measurements of cultures/reaction mixtures were performed using the Hitachi U-1900 spectrophotometer (Thermo Fisher Scientific, Waltham, MA, USA) at 600/420 nm. Vertical gel electrophoresis was performed using the Mini-protean Tetra Cell apparatus (Bio-Rad, Hercules, CA, USA).

\section{Screening for proteolytic strains}

The bacterial strain $\mathrm{H} 11$ used in this study was isolated as described in Kalwasińska et al. (25) from the top layer of the highly saline soda lime $\left(6.4 \% \mathrm{Cl}^{-}\right)$, a byproduct of soda production, deposited at the repository ponds in Janikowo, Kuyavia, central Poland. For the evaluation of the proteolytic properties of the isolate, a nutrient medium containing (in $\mathrm{g} / \mathrm{L}$ ): sodium caseinate 15, glucose 5, yeast extract 1, peptone $7.5, \mathrm{NaCl} 30$, $\mathrm{MgSO}_{4} \cdot 7 \mathrm{H}_{2} \mathrm{O}, 0.02, \mathrm{Na}_{2} \mathrm{CO}_{3} 2, \mathrm{~K}_{2} \mathrm{HPO}_{4} 0.2$ and agar $15 ; \mathrm{pH}=9$, was used. The solution containing glucose and $\mathrm{Na}_{2} \mathrm{CO}_{3}$ was autoclaved separately and cooled down before its addition to the medium. The plates were incubated at $26^{\circ} \mathrm{C}$ for 7 days. Protein hydrolysis was detected by Frazier's reagent $\left(12 \mathrm{~g} \mathrm{HgCl}_{2}, 80 \mathrm{~mL}\right.$ distilled water, $20 \mathrm{~mL}$ concentrated $\mathrm{HCl}$ ). Among all the proteolytic bacteria, one particular strain, $\mathrm{H} 11$, showing the largest bright arc, was chosen for further research aiming at the production and characterization of protease.

\section{Strain identification}

Identification of the isolated strain was based on the $16 \mathrm{~S}$ rRNA gene sequence described previously (25). The obtained nucleotide sequence was deposited in GenBank, NCBI, Bethesda, MD, USA, under the accession number KJ870251. The strain was preserved with glycerol stock $(20 \%)$ and stored at $-80^{\circ} \mathrm{C}$.

\section{Growth conditions}

The study included the determination of the optimal $\mathrm{pH}$, salinity and incubation temperature. The strain $\mathrm{H} 11$ identified as Bacillus luteus was grown in a medium described above, except for the addition of sodium caseinate. The $\mathrm{pH}$ was investigated in the range of $7-11$. The amount of $\mathrm{NaCl}$ was $0-9 \%$ and the temperature was $10-40^{\circ} \mathrm{C}$. All experiments were performed in triplicate with shaking at $150 \mathrm{rpm}$. Bacterial growth was monitored by the absorbance measurements of cultures at $600 \mathrm{~nm}$.

\section{Alkaline protease production}

A volume of $50 \mathrm{~mL}$ of the alkaline and saline medium containing (in $\mathrm{g} / \mathrm{L}$ ): peptone 7.5 , glucose 5 , yeast extract $1, \mathrm{NaCl}$ $50, \mathrm{Na}_{2} \mathrm{CO}_{3} 2, \mathrm{~K}_{2} \mathrm{HPO}_{4} 0.2$ and $\mathrm{MgSO}_{4} \cdot 7 \mathrm{H}_{2} \mathrm{O} 0.02, \mathrm{pH}=9$, was inoculated with $1 \mathrm{~mL}$ Bacillus luteus $\mathrm{H} 11$ suspension $\left(A_{600 \mathrm{~nm}}=1.0\right)$ and incubated at the optimal strain growth conditions of $30^{\circ} \mathrm{C}$ for $72 \mathrm{~h}$ with shaking at $150 \mathrm{rpm}$. The culture was centrifuged at $6000 \times \mathrm{g}$ and $4{ }^{\circ} \mathrm{C}$ for $10 \mathrm{~min}$, and the alkaline protease activity was measured. In order to investigate the effect of different nitrogen sources on the alkaline protease production, beef extract, tryptone and shrimp shell powder were used instead of peptone and yeast extract. The shrimp shell powder was obtained from dried shrimp waste $\left(105^{\circ} \mathrm{C}\right)$ after grinding in the Zelmer blender ZHB1220B (Głogów Małopolski, Poland) and sterilization at $117^{\circ} \mathrm{C}$ for $20 \mathrm{~min}$. The effects of different 
amounts of the nitrogen sources (0.5-2.5\%) on the enzyme production were also investigated. To assess the influence of different carbon sources on the bacterial growth and protease production, fructose, maltose, sucrose, and starch were used $(0.5$ $\% \mathrm{~m} / \mathrm{V}$ ) instead of glucose. In order to prevent acidification of the medium through fermentation of sugars, $100 \mathrm{mM}$ Tris- $\mathrm{HCl}$ (approx. $50 \mathrm{~mL}$ for each culture), $\mathrm{pH}=8.8$, was applied. Such buffered conditions enabled to maintain the alkaline $\mathrm{pH}$ of cultures during the three days of the experiment. Different amounts of $\mathrm{NaCl}$ (1-9\%) along with the best nitrogen and carbon sources were applied to investigate the optimal salt concentration for the protease production. All experiments were performed in three parallel repetitions, and the mean values were reported.

\section{Protease activity assay}

Protease activity was measured according to Jankiewicz et al. (27) using azocasein as the substrate. Briefly, $300 \mu \mathrm{L}$ of the enzyme were mixed with $300 \mu \mathrm{L}$ of $0.5 \%(\mathrm{~m} / \mathrm{M})$ azocasein in $100 \mathrm{mM}$ Tris- $\mathrm{HCl}$ buffer $(\mathrm{pH}=8.8)$. After incubation at $40^{\circ} \mathrm{C}$ for $30 \mathrm{~min}$, the reaction was stopped by adding $600 \mu \mathrm{L}$ of 10 $\%$ trichloroacetic acid (TCA). In the control sample, $300 \mu \mathrm{L}$ of the enzyme were mixed with $600 \mu \mathrm{L}$ of $10 \%$ TCA and $300 \mu \mathrm{L}$ of azocasein were added after incubation. The solution was centrifuged at $10000 \times g$ and the absorbance was measured at $420 \mathrm{~nm}$ and compared to the control sample.

Calibration curve which enables to calculate the mass correlation between the used substrate and the measured absorbance in the post-digestion sample was made according to Coêlho et al. (28). In order to do this, digestion of azocasein at the concentration of $0.3-1.5 \mathrm{mg} / \mathrm{mL}$ at $180 \mathrm{~min}$ by purified enzyme at the optimal conditions $\left(40^{\circ} \mathrm{C}, \mathrm{pH}=10.5\right.$ and $\left.3 \mathrm{M} \mathrm{NaCl}\right)$ was carried out (data not shown) and the calibration curve was obtained by plotting the azocasein concentration against its correspondent absorbance at $180 \mathrm{~min}$ (Fig. 1).

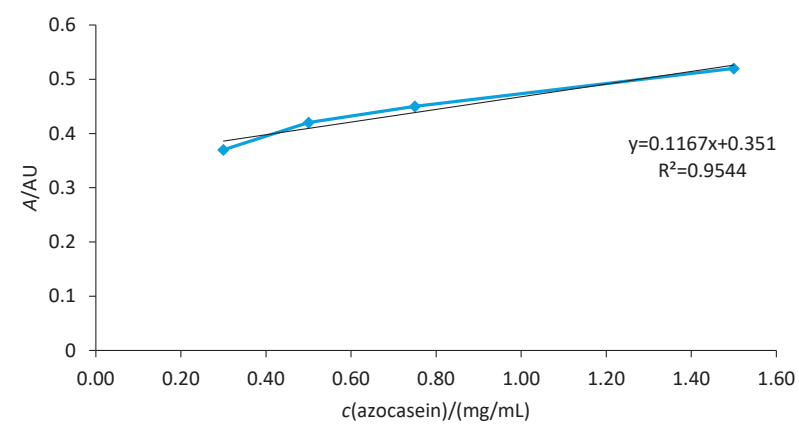

Fig. 1. Calibration curve for azocasein concentration $0.3-1.5 \mathrm{mg} / \mathrm{mL}$ after 180 min of digestion under the optimal conditions: $40^{\circ} \mathrm{C}, \mathrm{pH}=10.5$ and $3 \mathrm{M} \mathrm{NaCl}$

Azocasein concentration was calculated from the following equation:

$$
c(\text { azocasein })=\frac{A_{420 \mathrm{~nm}}-0.351}{0.1167}
$$

where $A_{420 \mathrm{~nm}}$ is the absorbance of azocasein. Therefore, one unit $(U)$ of the protease activity was defined as the amount of enzyme capable of digesting $1 \mathrm{mg}$ substrate per minute, as given in the following equation:

$$
\text { Activity }=\frac{c(\text { azocasein }) \cdot V^{2} \text { total }}{t \cdot V_{\text {enzyme }}}
$$

where $V_{\text {total }}$ is the sum of volumes of substrate, enzyme and TCA, $V_{\text {enzyme }}$ is the enzyme volume used in the digestion, and $t$ is the digestion time (min).

\section{Enzyme purification}

To obtain a clear supernatant, on the third day of growth at $30^{\circ} \mathrm{C}$, the bacterial culture was filtered and centrifuged at $9000 \times g$ for $10 \mathrm{~min}$. The production medium contained ( $\%, \mathrm{~m} / \mathrm{V})$ shrimp shell powder 2.5 and fructose 0.5 , as the optimum nitrogen and carbon source, respectively, and $\mathrm{NaCl} 4(\mathrm{pH}=9)$. The protease was purified in a two-step procedure consisting of ammonium sulphate precipitation (35-85 \% saturation) and molecular sieve chromatography. All protein purification stages were performed at $4{ }^{\circ} \mathrm{C}$. Fractionation with ammonium sulphate was performed by salting out the enzyme preparation to $35 \%$ of saturation in the first, and to $85 \%$ of saturation in the second step. To dissolve the pellet, $50 \mathrm{mM}$ Tris- $\mathrm{HCl}$ buffer, $\mathrm{pH}=8.8$, with $2 \mathrm{M} \mathrm{NaCl}$ was used and the solution was dialyzed overnight against the same buffer. Prior to the enzyme purification, a Superdex 200 column (Sigma-Aldrich) was equilibrated with $50 \mathrm{mM}$ Tris- $\mathrm{HCl}, \mathrm{pH}=8.8$, containing $2 \mathrm{M} \mathrm{NaCl}$. Then, the 10fold concentrated preparation was applied on the column. The active fractions were used to characterize the enzyme.

\section{Determination of protein content}

The protein concentration at all purification stages was determined with bovine serum albumin as a standard according to Bradford (29).

\section{SDS-PAGE electrophoresis and zymograms}

The electrophoretic separation of the samples using $10 \%$ sodium dodecyl sulfate (SDS) $(m / V)$ was carried out according to Laemmli (30). Zymograms were obtained after the electrophoretic separation of the samples under semi-denaturing conditions (without thermal denaturation). The polyacrylamide gel contained $0.1 \%$ azocasein. Upon completion of the electrophoresis, the gels were placed in $0.5 \%(\mathrm{~m} / \mathrm{M})$ Triton X-100 solution for $1 \mathrm{~h}$, then transferred into $100 \mathrm{mM}$ Tris-HCl buffer, $\mathrm{pH}=8.8$, and stained with $0.1 \%(\mathrm{~m} / \mathrm{V})$ amide black solution. The bright bands against the dark blue background of the gel indicated the proteolytic activity.

\section{Effect of $\mathrm{pH}$, salinity, temperature, and various chemical agents on protease activity and substrate specificity}

Protease activity was studied over a $\mathrm{pH}$ range from 4 to 13 using $50 \mathrm{mM}$ Britton-Robinson buffer. The effect of $\mathrm{NaCl}$ on 
enzyme activity was tested at various $\mathrm{NaCl}$ concentrations (1, 2, 3,4 and $5 \mathrm{M}$ ). The effect of temperature was studied at 30, 40, 50 and $60^{\circ} \mathrm{C}$. The thermal stability was determined at 45,55 and 65 ${ }^{\circ} \mathrm{C}$ after 30, 60, 90 min of pre-incubation of the enzyme.

In order to assess the effect of specific protease inhibitors, metal ions, and other chemicals, the purified enzyme was preincubated in the presence of a given compound at $4{ }^{\circ} \mathrm{C}$ for 30 min, and then the residual protease activity was measured as described in the protease activity assay.

The inhibitors included: aprotinin (final concentrations 100 $\mathrm{nM}$ and $1 \mu \mathrm{M}$ ), Na-tosyl--L-lysine chloromethyl ketone hydrochloride (TLCK) (final concentrations 1.0 and $10.0 \mu \mathrm{M}$ ), diisopropyl phosphorofluoridate (DFP), ethylene-bis(oxyethylenenitrilo) tetraacetic acid tetrasodium (EGTA), ethylenediaminetetraacetic acid (EDTA), Pefabloc ${ }^{\circledast}$, phenylmethylsulfonyl fluoride (PMSF), pepstatin A, 1,10-phenanthroline, iodoacetamide, E-64, and 10-phenantroline (final concentrations 0.1 and $1.0 \mathrm{mM}$ ). The metal ions included: $\mathrm{Mg}^{2+} \mathrm{Ca}^{2+}, \mathrm{Ba}^{2+}, \mathrm{Co}^{2+}, \mathrm{Fe}^{2+}, \mathrm{Cu}^{2+}, \mathrm{Zn}^{2+}, \mathrm{Cd}^{+}(\mathrm{fi}-$ nal concentrations 1 and $5 \mathrm{mM})$. Other chemicals were: cetyl trimethylammonium bromide (CTAB), dimethyl sulfoxide (DMSO), ethanol, $2 \mathrm{M}, \mathrm{H}_{2} \mathrm{O}_{2}$, sodium dodecyl sulphate (SDS), Triton X-100, Tween 80, and urea (final concentrations 1.0 and $5.0 \mathrm{mM}$ ).

Solvents used in this study were: acetone, butanol, ethanol, and methanol. The solutions were prepared at the concentrations of 50 and $75 \%$ by volume. Prior to the 1-hour incubation of the enzyme with the solvent, the substrate for protease was added and the residual activity was measured.

Substrate specificity was determined using N-succinyl-Gly-Gly-Phe- $p$-nitroanilide, N-succinyl-L-phenylalanine- $p$-nitroanilide, Na-benzoyl-L-arginine 4-nitroanilide hydrochloride, and Z-Gly-Gly-Leu- $p$-nitroanilide. The activity of protease was measured according to Bezerra et al. (31) and defined as $\mu \mathrm{mol}$ nitrophenol per $1 \mathrm{~h}$. Briefly, $50 \mu \mathrm{L}$ of the purified enzyme were mixed with $150 \mu \mathrm{L} 50 \mathrm{mM}$ Tris- $\mathrm{HCl}(\mathrm{pH}=9)$ containing $1 \mathrm{M} \mathrm{NaCl}$. After 5 min of preincubation, $50 \mu \mathrm{L}$ of the appropriate substrate $(5 \mathrm{mM}$ in DMSO) were added, and the mixture was incubated at $40^{\circ} \mathrm{C}$ for $15 \mathrm{~min}$. Then, the activity of protease was measured at $420 \mathrm{~nm}$.

\section{RESULTS AND DISCUSSION}

\section{Proteolytic bacterium}

The strain $\mathrm{H} 11$ isolated from the highly alkaline and saline soda lime was a rod-shaped Gram-positive bacterium that grew at $\mathrm{pH}$ range from 7.0 to 11.0 and at temperatures from 10 to 40 ${ }^{\circ} \mathrm{C}$. The optimal conditions for the growth were: $\mathrm{pH}=9,5-6 \%$ $\mathrm{NaCl}$ concentration and a temperature of $30^{\circ} \mathrm{C}$. The isolate was found to be alkaliphilic and moderately halophilic. The strain $\mathrm{H} 11$ was assigned to the genus Bacillus, and it was closely related to Bacillus luteus (25).

\section{Production of protease}

Shrimp shell powder and fructose/glucose ( 2.5 and $0.5 \%$ $m /$, respectively) were the optimal nitrogen and carbon sources for the production of protease by Bacillus luteus $\mathrm{H} 11$ (Figs.
$2 \mathrm{a}$ and $2 \mathrm{~b}$ ). One of the most important challenges in enzyme production is reduction of production costs related to high expenses of substrates and media used. To achieve these goals, efforts have been made to reduce the protease production costs through both improving the enzyme yield, and the use of low-cost agricultural byproducts, wastes, or feedstocks as substrates for protease production $(32,33)$. Similarly to the results obtained in this study, the shrimp shell powder was identified as the best substrate/inducer for the production of proteases by Chryseobacterium taeanense (34), Bacillus cereus TKU006 (35), Bacillus cereus $\mathrm{SV}_{1}$ (36) and Bacillus halodurans CAS6 (37). The optimal conditions for growth and protease production of Bacillus luteus $\mathrm{H} 11$ were $\mathrm{pH}=9.0, \mathrm{NaCl}$ mass per volume ratio of $4 \%$, and a temperature of $30^{\circ} \mathrm{C}$. Comparable results were obtained for B. alcalophilus, isolated from a saline soda lake, Lonar Lake, India (38). In our study, protease production increased with increasing salinity $(1-9 \% \mathrm{NaCl}, \mathrm{m} / \mathrm{M}$ ) and reached its maximum at $4-5 \% \mathrm{NaCl}$ (Fig. 2c). Similar to the results of the present study, Bacillus subtilis AP-MSU6 produced protease that had the optimal salinity of $5 \%$ $\mathrm{NaCl}$ (39). However, moderate Gram-positive halophiles often reduce the enzyme production at a high salt concentration $(2,40)$.
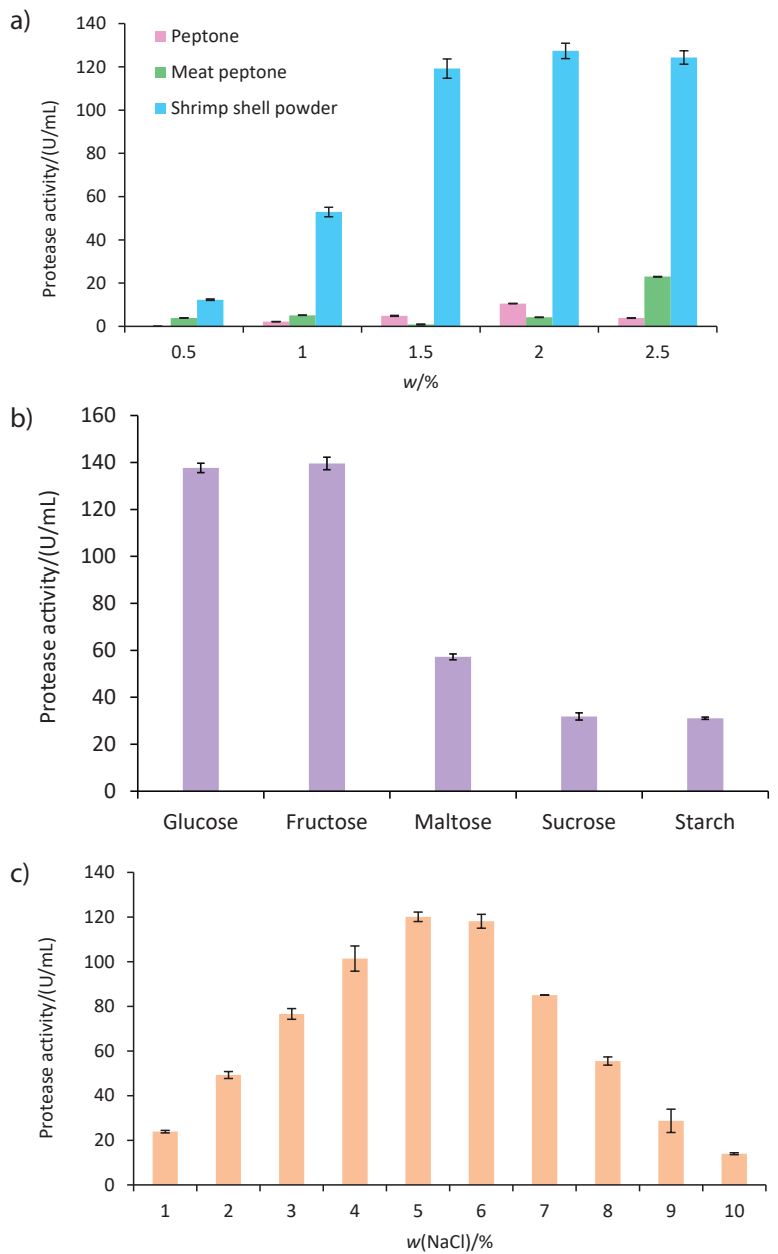

Fig. 2. Effect of: a) nitrogen and b) carbon $(0.5 \% \mathrm{~m} / \mathrm{V})$ sources, and c) amounts of $\mathrm{NaCl}$ on the activity of protease from Bacillus luteus $\mathrm{H} 11$. The study was evaluated by incubating bacterial culture for $72 \mathrm{~h}$ under optimal growth conditions: $30^{\circ} \mathrm{C}, \mathrm{pH}=9$, and $5 \% \mathrm{NaCl}$ (a and b), $30^{\circ} \mathrm{C}$ and $\mathrm{pH}=9$ (c). Each value represents mean \pm S.D., $N=3$ 


\section{Protease purification and molecular mass determination}

The enzyme was purified 1.2 times ( $75.9 \%$ recovery) in the first and 8.3 times $(16.5 \%)$ in the second step of the process. The specific activity of the protease was $115.2 \mathrm{U} / \mathrm{mg}$. The molecular mass of the purified enzyme was approx. $37 \mathrm{kDa}$ (Fig. 3), which is similar to the protease from halotolerant Virgibacillus dokdonensis VITP14 (36 kDa) (24), and different from Bacillus subtilis AP-MSU 6 (18.5 kDa) (39), B. halodurans CAS6 (28 kDa) (37) and Chromohalobacter TVSP101 (66 kDa) (40). a)

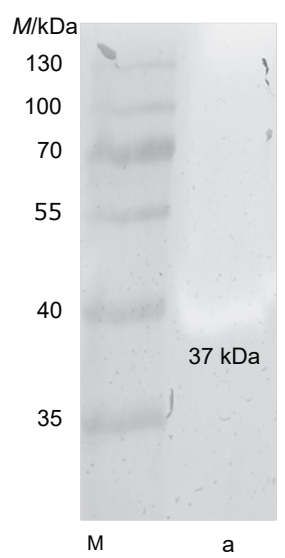

b)

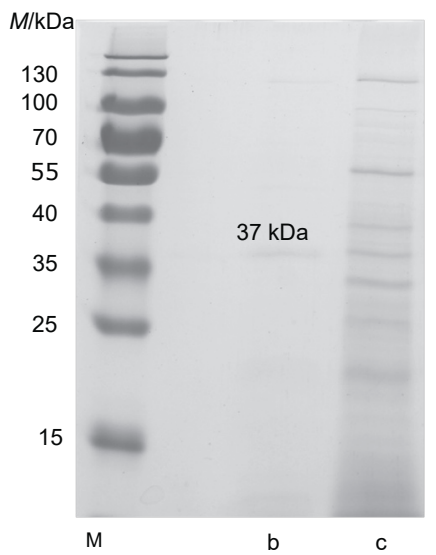

Fig. 3. The analyses of: a) zymograms and b) SDS-PAGE of protease from Bacillus luteus $\mathrm{H} 11 ; \mathrm{M}=$ standard molecular mass marker, a and $\mathrm{b}=$ purified protease, $\mathrm{c}=$ crude protein extract

\section{Effect of $\mathrm{pH}$, salinity, and temperature on protease activity}

The purified enzyme showed optimum activity at $\mathrm{pH}=10.5$ and in $3 \mathrm{M} \mathrm{NaCl}$ (Fig. 4). The high activity was maintained in the broad $\mathrm{pH}$ and salinity range, from 9 to 11 , and from 1 to $5 \mathrm{M} \mathrm{NaCl}$, respectively. The remarkable ability of the enzyme to perform its functions in a highly saline environment is similar to halophilic archeal strains such as Natronolimnobius innermongolicus WN18 (optimal protease activity at $2.5 \mathrm{M} \mathrm{NaCl}$ ) and Haloferax lucentensis VKMM 007 (4.3 M NaCl) and also to an extreme halophile Chromohalobacter TVSP101 (4.5 M NaCl). These microorganisms were isolated from saline environments with $\mathrm{NaCl}$ concentration close to saturation such as soda lake, brine, and solar salterns $(14,40-43)$.

In terms of $\mathrm{pH}$ range, the serine protease produced by $\mathrm{Ba}$ cillus luteus $\mathrm{H} 11$ is similar to Esperase ${ }^{\oplus} 8.0 \mathrm{~L}$ (Novozymes, Bagsværd, Denmark) intended for robust cleaning at high alkalinity and elevated temperatures (44).

The protease secreted by Bacillus luteus $\mathrm{H} 11$ worked best in a temperature interval from 40 to $50^{\circ} \mathrm{C}$ with the optimum activity at $45^{\circ} \mathrm{C}$ (Fig. 5). The thermostability of the enzyme was measured at 45,55 and $65^{\circ} \mathrm{C}$. The results showed that at 45 and 55 ${ }^{\circ} \mathrm{C}$, after $60 \mathrm{~min}$, the enzyme activity was maintained at 85 and $70 \%$ respectively, while at $65^{\circ} \mathrm{C}$ the enzyme maintained only approx. $30 \%$ of its activity (Fig. 6). For most of the halophilic proteases, the reported temperature optimum was in the range from 37 to $75^{\circ} \mathrm{C}(14,40-43)$. The thermostability of the protease from Bacillus luteus $\mathrm{H} 11$ at 30 and $40^{\circ} \mathrm{C}$, along with its tolerance
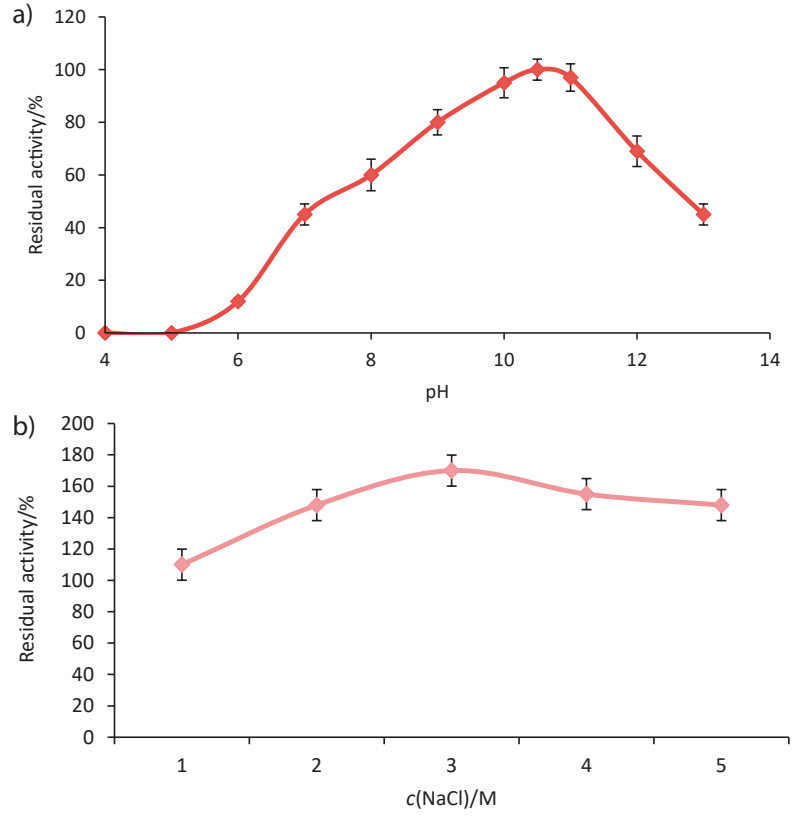

Fig. 4. Effect of $\mathrm{pH}$ and $\mathrm{NaCl}$ concentration on the activity of protease from Bacillus luteus $\mathrm{H} 11$. The study was evaluated by incubating purified enzyme substrate for 30 min under its optimal growth conditions: a) $45^{\circ} \mathrm{C}$ and $3 \mathrm{M} \mathrm{NaCl}$ and b) $\mathrm{pH}=10.5$ and $45^{\circ} \mathrm{C}$. Each value represents mean \pm S.D., $N=3$

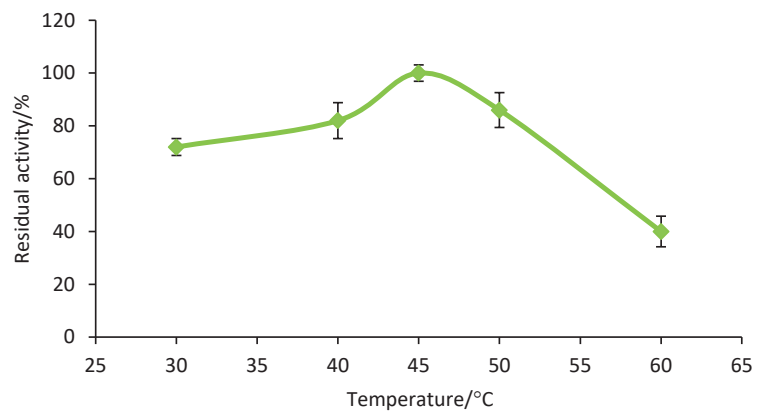

Fig. 5. Effect of temperature on the activity of protease from Bacillus luteus $\mathrm{H} 11$. The study was evaluated by incubating purified enzyme substrate in $3 \mathrm{M} \mathrm{NaCl}$ at $\mathrm{pH}=10.5$ for $30 \mathrm{~min}$. Each value represents mean \pm S.D., $N=3$

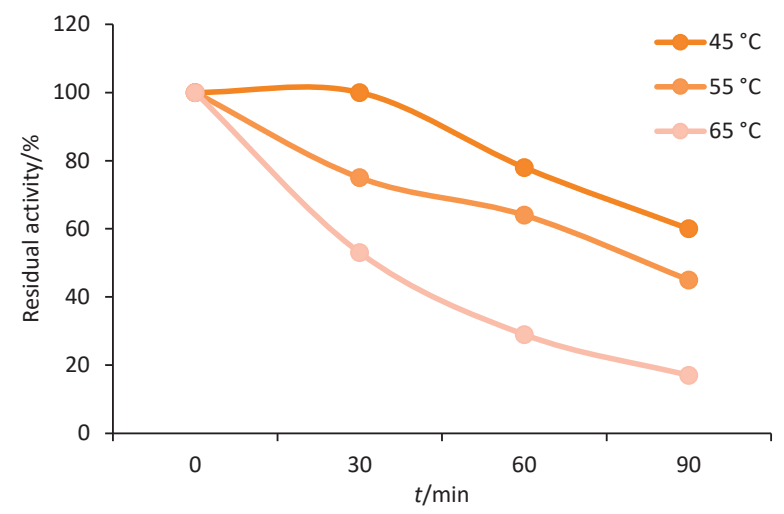

Fig. 6. Thermal stability of protease from Bacillus /uteus H11. The study was evaluated by incubating purified enzyme in $3 \mathrm{M} \mathrm{NaCl}$ at $\mathrm{pH}=10.5$ for $90 \mathrm{~min}$ at different temperatures $\left(45,55\right.$ and $\left.65^{\circ} \mathrm{C}\right)$. Each value represents mean \pm S.D., $N=3$ 
to alkalinity makes it useful for its potential application in detergents designed for washing at low temperatures. Rising energy costs and increased use of artificial fibres of low tolerance towards high temperatures force the enzyme manufacturers to search for novel biocatalysts, active at low temperatures (45).

\section{Effect of specific inhibitors on enzyme activity and substrate specificity}

In this study, specific serine protease inhibitors, Pefabloc and DFP inhibited the activity of the enzyme at the 82-95\% level and phenylmethylsulfonyl fluoride (PMSF) at the 58-75 $\%$ level (Table 1). Other investigated protease inhibitors such as bestatin, E-64, iodoacetamide, and pepstatin A did not affect the enzyme activity. It can be concluded that extracellular protease from Bacillus luteus $\mathrm{H} 11$ is a serine protease since the classical serine protease inhibitors, Pefabloc and PMSF, reduce its catalytic ability. In addition, the relatively high enzyme activity in the presence of TLCK and aprotinin suggests the lack of a mechanism specific to trypsin-like endoprotease. On the other hand, no effect of bestatin on the activity of protease precludes its belonging to aminopeptidase, particularly to leucine aminopeptidase. The protease activity produced by alkaline and halophilic marine Bacillus subtilis AP-MSU6 studied by Maruthiah et al. (39) was strongly inhibited in the presence of PMSF and thus it was confirmed as a serine protease. Similar serine protease was also observed in B. mojavensis A21 (46) and Bacillus sp. (47). The studied endoprotease was active only in the presence of $\mathrm{N}$-succinyl-L-phenylalanine- $p$-nitroanilide as a substrate (data not shown). The obtained results allow classifying the enzyme among the subtilisin-like proteases, having a serine group in their active site. Such substrate specificity of extracellular endoproteases is typical for Bacillus species. Many alkaline, serine proteases have found practical application in biotechnology (48), e.g. Alcalase, Savinase, Esperase, Neutrase (Novozymes).

Table 1. Effects of specific inhibitors on the protease activity

\begin{tabular}{lcc} 
& \multicolumn{2}{c}{ Residual activity/\% } \\
\cline { 2 - 3 } c(inhibitor)/mM & 0.1 & 1 \\
none & 100 & 100 \\
DFP & 10 & 5 \\
Pefabloc & 18 & 9 \\
PMSF & 40 & 25 \\
EDTA & 99 & 95 \\
EGTA & 90 & 90 \\
1,10-Phenanthroline & 100 & 95 \\
lodoacetamide & 100 & 100 \\
E-64 & 100 & 100 \\
Pepstatin A & 100 & 100 \\
& $10^{-3}$ & $10^{-2}$ \\
Bestatin & 100 & 100 \\
TLCK & 100 & 100 \\
& $10^{-4}$ & $10^{-3}$ \\
Aprotinin & 100 & 100
\end{tabular}

$\mathrm{DFP}=$ diisopropyl fluorophosphates, $\mathrm{PMSF}=$ phenylmethylsulfonyl fluoride, EDTA=ethylenediaminetetraacetic acid, EGTA=ethylenebis(oxyethylenenitrilo)tetraacetic acid tetrasodium, TLCK= Na-tosyl-L-lysine chloromethyl ketone hydrochloride

\section{Effect of other chemical reagents including metal ions on} enzyme activity

The protease activity was strongly inhibited by $\mathrm{Zn}^{2+}$ and stabilized by $\mathrm{Ca}^{2+}$ and $\mathrm{Mg}^{2+}$ (Table 2). A similar effect of a strong protease inhibition by $\mathrm{Zn}^{2+}$ was observed by Vidyasagar et al. (40), while simulatory effects of $\mathrm{Ca}^{2+}$ and $\mathrm{Mg}^{2+}$ were detected by Deng et al. (49) and Maruthiah et al. (39) when using alkaline protease from Bacillus sp. B001 and Bacillus subtilis AP-MSU6, respectively.

In the present study organic solvents inhibited the proteolytic activity of Bacillus luteus $\mathrm{H} 11$; however, the enzyme retained more than half of the initial activity (Table 2 ). Mesbah and Wiegel (50) showed that the protease from Alkalibacillus sp. NM-Fa4 was even more active in the presence of ethanol, showing $123 \%$ of its initial activity, and retained 74 $\%$ of activity in the presence of methanol ( $50 \%$, by volume). According to Annamalai et al. (51), the enzyme from alkaline Bacillus firmus CAS 7 was enhanced with isopropanol (115.6 $\%)$ and acetonitrile (105.4\%), whereas methanol (90.3\%), ethanol (86.2 \%), hexane (85.7\%) and ethyl ether (81.3\%) (25\% final, by volume) did not have significant effect on its activity. In the present study, other chemicals such as DMSO, $2 \mathrm{M}$ ethanol, urea and $\mathrm{H}_{2} \mathrm{O}_{2}$, Tween 80 and Triton X-100 (1 mM) did not inhibit the protease activity (Table 2). Study made by Raval et al. (52) on purified protease from haloalkaliphilic

Table 2. Effect of metal ions, solvents and other chemical reagents on the protease activity

\begin{tabular}{|c|c|c|}
\hline \multirow[b]{2}{*}{$c($ inhibitor $) / \mathrm{mM}$} & \multicolumn{2}{|c|}{ Residual activity/\% } \\
\hline & 1 & 5 \\
\hline none & 100 & 100 \\
\hline $\mathrm{Mg}^{2+}$ & 120 & 119 \\
\hline $\mathrm{Ca}^{2+}$ & 128 & 120 \\
\hline $\mathrm{Ba}^{2+}$ & 100 & 95 \\
\hline $\mathrm{Co}^{2+}$ & 100 & 90 \\
\hline $\mathrm{Fe}^{2+}$ & 75 & 70 \\
\hline $\mathrm{Cu}^{2+}$ & 74 & 60 \\
\hline $\mathrm{Zn}^{2+}$ & 15 & 5 \\
\hline $\mathrm{Cd}^{+}$ & 90 & 85 \\
\hline$\varphi$ (solvent) $/ \%$ & 50 & 75 \\
\hline Butanol & 55 & 45 \\
\hline Methanol & 70 & 51 \\
\hline Ethanol & 67 & 60 \\
\hline Acetone & 70 & 50 \\
\hline$c($ substance $) / \mathrm{mM}$ & 1 & 5 \\
\hline SDS & 87 & 75 \\
\hline Triton X-100 & 100 & 85 \\
\hline Tween 80 & 106 & 87 \\
\hline CTAB & 95 & 80 \\
\hline DMSO & 100 & 105 \\
\hline $2 \mathrm{M}$ ethanol & 105 & 110 \\
\hline Urea & 100 & 100 \\
\hline $\mathrm{H}_{2} \mathrm{O}_{2}$ & 100 & 100 \\
\hline
\end{tabular}

$\mathrm{SDS}=$ sodium dodecyl sulphate, $\mathrm{CTAB}=$ cetyl trimethylammonium bromide, $\mathrm{DMSO}=$ dimethyl sulfoxide 
Bacillus pseudofirmus revealed that the enzyme showed a relatively high activity in non-ionic surfactants (Tween 80 and Triton X-100, $1 \%$ by volume), commercial detergents, oxidizing and reducing agents, while it was not stable in anionic surfactant ( $1 \%$ SDS, $m / V$ ). Mesbah and Wiegel (50) reported that an haloalkaline, thermostable protease produced by $\mathrm{Al}$ kalibacillus sp. NM-Fa4 was resistant to SDS, $\mathrm{H}_{2} \mathrm{O}_{2}$ and urea, and retained most of its activity in the presence of Tween 80 $(1 \%, m / V)$.

\section{CONCLUSIONS}

The serine, subtilisin-like endoprotease, produced by $\mathrm{Ba}$ cillus luteus $\mathrm{H} 11$ isolated from alkaline and saline soda lime was purified and characterized. The alkaline protease secreted by $B$. luteus $\mathrm{H} 11$ may be important from industrial perspective because of its tolerance towards high alkalinity and salinity, as well as its stability against surfactants, some organic solvents, and oxidants. These characteristics make the protease useful for applications in the food, detergent, and pharmaceutical industries, as well as in environmental bioremediation. To the best of our knowledge, there is currently a lack of commercial alkaline protease on the market showing such a particular halotolerance. The possibility of using wastes from shrimp processing for the haloalkaline protease production is promising, both in lowering the overall cost of the biocatalyst production and waste utilization.

\section{FUNDING}

This research was supported by funds provided by Nicolaus Copernicus University (Toruń Poland) and partly by Warsaw University of Life Sciences to maintain research potential.

\section{CONFLICT OF INTEREST}

The authors declare no conflict of interest.

\section{REFERENCES}

1. Eichler J. Biotechnological uses of archaeal extremozymes. Biotechnol Adv. 2001;19:261-78. https://doi.org/10.1016/S0734-9750(01)00061-1

2. van den Burg B. Extremophiles as a source for novel enzymes. Curr Opin Microbiol. 2003; 6:213-8.

https://doi.org/10.1016/S0734-9750(01)00061-1

3. Annamalai N, Rajeswari MV, Balasubramanian T. Extraction, purification and application of thermostable and halostable alkaline protease from Bacillus alveayuensis CAS 5 using marine wastes. Proteins: Struct Funct Bioinf. 2014;92:335-42. https://doi.org/10.1016/j.fbp.2013.08.009

4. Joshi S, Satyanarayana T. Characteristics and applications of a recombinant alkaline serine protease from a novel bacterium Bacillus lehensis. Bioresour Technol. 2013;131:76-85. https://doi.org/10.1016/j.biortech.2012.12.124
5. Abdelnasser SSI, Salamah AAA, Elbadawi YB, Tayeb MAE, Ibrahim SS. Production of extracellular alkaline protease by new halotolerant alkaliphilic Bacillus sp. NPST-AK15 isolated from hyper saline soda lakes. Electron J Biotechnol. 2015;18:236-43.

https://doi.org/10.1016/j.ejbt.2015.04.001

6. Shah K, Mody K, Keshri J, Jha B. Purification and characterization of a solvent, detergent and oxidizing agent tolerant protease from Bacillus cereus isolated from the Gulf of Khambhat Kunal. J Mol Catal B: Enzym. 2010;67:85-91. https://doi.org/10.1016/j.molcatb.2010.07.010

7. Kumar RS, Ananthan G, Prabhu AS. Optimization of medium composition for alkaline protease production by Marinobacter sp. GA CAS9 using response surface methodology A statistical approach. Biocatal Agri Biotechnol. 2014;3:191-7. https://doi.org/10.1016/j.bcab.2013.11.005

8. Gómez J, Steiner W. The biocatalytic potential of extremophiles and extremozymes. Food Technol Biotechnol. 2004; 42:223-35.

9. Oren A. Industrial and environmental applications of halophilic microorganisms. Environ Technol. 2010;31:825-34. https://doi.org/10.1080/09593330903370026

10. Li X, Yu HY. Characterization of an organic solvent-tolerant a-amylase from a halophilic isolate, Thalassobacillus sp. LY18. Folia Microbiol. 2012;57:447-53. https://doi.org/10.1007/s12223-012-0160-3

11. Gupta S, Sharma P, Dev K, Srivastava M, Sourirajan A. A diverse group of halophilic bacteria exist in Lunsu, a natural salt water body of Himachal Pradesh, India. SpringerPlus 2015;4(1):274-83.

https://doi.org/10.1186/s40064-015-1028-1

12. Klähn S, Marquardt DM, Rollwitz I, Hagemann M. Expression of the ggpPS gene for glucosylglycerol biosynthesis from Azotobacter vinelandii improves the salt tolerance of Arabidopsis thaliana. J Exp Bot. 2009;60:1679-89. https://doi.org/10.1093/jxb/erp030

13. Arora S, Patel P, Vanza M, Rao GG. Isolation and characterization of endophytic bacteria colonizing halophyte and other salt-tolerant plant species from coastal Gujarat. Afr J Microbiol Res. 2014;8:1779-88.

https://doi.org/10.5897/AJMR2013.5557

14. Selim S, Hagagy N, Aziz MA, El-Meleigy S, Pessione E. Thermostable alkaline halophilic-protease production by Natronolimnobius innermongolicus WN18. Nat Prod Res. 2014;28:1476-9.

https://doi.org/10.1080/14786419.2014.907288

15. Fujinami S, Fujisawa M. Industrial applications of alkaliphiles and their enzymes - Past, present and future. Environ Technol. 2010;31:845-56.

https://doi.org/10.1080/09593331003762807

16. Joo HS, Chang CS. Oxidant and SDS-stable alkaline protease from a halo-tolerant Bacillus clausii I-52: Enhanced production 
and simple purification. J Appl Microbiol. 2005;98:491-7. https://doi.org/10.1111/j.1365-2672.2004.02464.x

17. Setyorini E, Takenaka S, Murakami S, Aoki K. Purification and characterization of two novel halotolerant extracellular proteases from Bacillus subtilis strain FP-133. Biosci Biotech Biochem. 2006;70:433-40.

https://doi.org/10.1271/bbb.70.433

18. Alvarez VM, von der Weid I, Seldin L, Santos ALS. Influence of growth conditions on the production of extracellular proteolytic enzymes in Paenibacillus peoriae NRRL BD-62 and Paenibacillus polymyxa SCE2. Lett Appl Microbiol. 2006;43: 625-30.

https://doi.org/ 10.1111/j.1472-765X.2006.02015.x

19. Namwong S, Hiraga K, Takada K, Tsunemi M, Tanasupawat S, Oda K. A halophilic serine proteinase from Halobacillus sp. SR5-3 isolated from fish sauce: purification and characterization. Biosci Biotechnol Biochem. 2006;70:1395-401. https://doi.org/10.1271/bbb.50658

20. Akolkar AV, Durai D, Desai AJ. Halobacterium sp. SP1(1) as a starter culture for accelerating fish sauce fermentation. J Appl Microbiol. 2010;109:44-53. https://doi.org/10.1111/j.1365-2672.2009.04626.x

21. Phrommao E, Rodtong S, Yongsawatdigul J. Identification of novel halotolerant bacillopeptidase F-like proteinases from a moderately halophilic bacterium, Virgibacillus sp. SK37. J Appl Microbiol. 2011;110:191-201.

https://doi.org/10.1111/j.1365-2672.2010.04871.x

22. Karan R, Khare SK. Stability of haloalkaliphilic Geomicrobium sp. protease modulated by salt. Biochemistry (Moscow) 2011;76:686-93.

https://doi.org/10.1134/S0006297911060095

23. Santos AF, Valle RS, Pacheco CA, Alvarez VM, Seldini L, Santos ALS. Extracellular proteases of Halobacillus blutaparonensis strain M9, a new moderately halophilic bacterium. Braz J Microbiol. 2013;44:1299-304.

https://doi.org/10.1590/S1517-83822014005000015

24. Rajeswari VD, Jayarman G, Sridharn TB. Purification and characterization of extracellular protease from halotolerant bacterium Virgibacillus dokdonensis VITP14. Asian J Biochem. 2012;7:123-32. https://doi.org/10.3923/ajb.2012.123.132

25. Kalwasińska A, Felföldi T, Walczak M, Kosobucki P. Physiology and molecular phylogeny of bacteria isolated from alkaline distillery lime. Pol J Microbiol. 2015;64: 69-77.

26. Reynolds III JE, Josowicz M, Tyler F, Vegh RB, Solntsev KM. Spectral and redox properties of the GFP synthetic chromophores as a function of $\mathrm{pH}$ in buffered media. Chem Commun. 2013;49(71):7788-90. https://doi.org/10.1039/C3CC44113J

27. Jankiewicz U, Larkowska E, Swiontek Brzezinska M. Production, characterization, gene cloning, and nematocidal activity of the extracellular protease from Stenotrophomonas maltophilia N4. J Biosci Bioeng. 2016;121:614-8.

https://doi.org/10.1016/j.jbiosc.2015.11.011

28. Coêlho DF, Saturnino TP, Fernandes FF, Mazzola PG, Silveira E, Tambourgi EB. Azocasein substrate for determination of proteolytic activity: Reexamining a traditional method using bromelain samples. BioMed Res Int. 2016;2016:Article ID 8409183.

https://doi.org/10.1155/2016/8409183

29. Bradford MM. A rapid and sensitive method for the quantitation of microgram quantities of protein utilizing the principle of protein-dye binding. Anal Biochem. 1976;72:248-54.

30. Laemmli UK. Cleavage of structural proteins during the assembly of the head of bacteriophage T4. Nature. 1970;227: 680-5.

31. Bezerra RS, Lins EJF, Alencar RB, Paiva PMG, Chaves MEC, Coelho LCBB, Carvalho Jr LB. Alkaline proteinase from intestine of Nile tilapia (Oreochromis niloticus). Process Biochem. 2005;40(5):1829-34.

https://doi.org/10.1016/j.procbio.2004.06.066

32. Mukherjee AK, Adhikari H, Rai SK. Production of alkaline protease by a thermophilic Bacillus subtilis under solid-state fermentation (SSF) condition using Imperata cylindrical grass and potato peel as a low-cost medium: Characterization and application in detergent formulation. Biochem Eng J. 2008;39:353-61.

https://doi.org/10.1016/j.bej.2007.09.017

33. Dutta M, Chamendra N, Pai SG, Pramod T, Siddalingeshwara KG. Isolation and screening of agro-waste substrates for protease production through solid state fermentation. Int J Curr Microbiol Appl Sci. 2014;3:774-81.

34. Wang SL, Yang CH, Liang TW, Yen YH. Optimization of conditions for protease production by Chryseobacterium taeanense TKU001. Bioresour Technol. 2008;99:3700-7.

https://doi.org/10.1016/j.biortech.2007.07.036

35. Wang SL, Chao CH, Liang TW, Chen CC. Purification and characterization of protease and chitinase from Bacillus cereus TKU006 and conversion of marine wastes by these enzymes. Mar Biotechnol. 2009;11:334-44.

https://doi.org/10.1007/s10126-008-9149-y

36. Ghorbel-Bellaaj O, Manni L, Jellouli K, Hmidet N, Nasri M. Optimization of protease and chitinase production by Bacillus cereus SV1 on shrimp shell waste using statistical experimental design. Biochemical and molecular characterization of the chitinase. Ann Microbiol. 2012;62:1255-68.

https://doi.org/10.1007/s13213-011-0371-x

37. Annamalai N, Rajeswari MV, Thavasi R, Vijayalakshmi S, Balasubramanian T. Optimization, purification and characterization of novel thermostable, haloalkaline, solvent stable protease from Bacillus halodurans CAS6 using marine shellfish wastes: A potential additive for detergent and antioxidant synthesis. Bioprocess Biosyst Eng. 2013;36:873-83. https://doi.org/10.1007/s00449-012-0820-3 
38. Kanekar PP, Nilegaonkar SS, Sarnaik SS, Kelkar AS. Optimization of protease activity of alkaliphilic bacteria isolated from an alkaline lake in India. Bioresour Technol. 2002;85:87-93.

39. Maruthiah T, Esakkiraj P, Prabakaran G, Palavesam A. Purification and characterization of moderately halophilic alkaline serine protease from marine Bacillus subtilis AP-MSU 6. Biocatal Agri Biotechnol. 2013;2:116-9. https://doi.org/10.1016/j.bcab.2013.03.001

40. Vidyasagar M, Prakash S, Mahajan V, Shouche YS, Sreeramulu K. Purification and characterization of an extreme halothermophilic protease from a halophilic bacterium Chromohalobacter sp. TVSP101. Braz J Microbiol. 2009;40:12-9. https://doi.org/10.1590/S1517-83822009000100002

41. Izotova LS, Strongin AY, Chekulaeva LW, Sterkin VE, Ostoslavskaya VI, Lyublinskaya EA, et al. Purification and properties of serine protease from Halobacterium halobium. J Bacteriol. 1983;155:826-30.

42. Kanlayakrit W, Bovornreungroj P, Oka T, Goto M. Production and characterization of a protease from an extremely halophilic Halobacterium sp. PB407. Kasetsart J (Nat Sci). 2004; 38:15-20.

43. Manikandan M, Pas L, Kannan V. Purification and biological characterization of a halophilic thermostable protease from Haloferax lucentensis VKMM 007. World J Microbiol Biotechnol. 2009;25:2247-56. https://doi.org/10.1007/s11274-009-0132-1

44. Esperase ${ }^{\circledR}$ 8.0L. Inc. Catalog \# 06-3115. Strem Chemicals, Newburyport, MA, USA. Available from: https://www.strem. com/uploads/technical_notes/06-3115tech.pdf.

45. Gupta R, Beg QK, Lorenz P. Bacterial alkaline proteases: molecular approaches and industrial applications. Appl Microbiol Biotechnol. 2002;59:15-32. https://doi.org/10.1007/s00253-002-0975-y

46. Haddar A, Agrebi R, Bougatef A, Hmidet N, Sellami-Kamoun A, Nasri M. Two detergent stable alkaline serine-proteases from Bacillus mojavensis A21: Purification, characterization and potential application as a laundry detergent additive. Bioresour Technol. 2009;100:3366-73. https://doi.org/10.1016/j.biortech.2009.01.061

47. Zambare V. Purification and characterization of neutral serine protease from Bacillus sp. Asiat J Biotechnol Resour. 2010;3:183-92.

https://doi.org/12.2010/AJOBR-2010/03/183-192

48. Parrado J, Rodriguez-Morgado B, Tejada M, Hernandez T, Garcia C. Proteomic analysis of enzyme production by Bacillus licheniformis using different feather wastes as the sole fermentation media. Enzyme Microb Technol. 2014;57:1-7. https://doi.org/10.1016/j.enzmictec.2014.01.001

49. Deng A, Wua J, Zhang Y, Zhang G, Wen T. Purification and characterization of a surfactant-stable high-alkaline protease from Bacillus sp. B001. Bioresour Technol. 2010;101: 7100-6.

https://doi.org/10.1016/j.biortech.2010.03.130

50. Mesbah NM, Wiegel J. Purification and biochemical characterization of halophilic, alkalithermophilic protease AbCP from Alkalibacillus sp. NM-Fa4. J Mol Catal B: Enzym. 2014; 105:74-81.

https://doi.org/10.1016/j.molcatb.2014.03.023

51. Annamalai N, Rajeswari MV, Sahu SK, Balasubramanian T. Purification and characterization of solvent stable, alkaline protease from Bacillus firmus CAS 7 by microbial conversion of marine wastes and molecular mechanism underlying solvent stability. Process Biochem. 2014;49:1012-9. https://doi.org/10.1016/j.procbio.2014.03.007

52. Raval VH, Pillai S, Rawal CM, Singh SP. Biochemical and structural characterization of a detergent-stable serine alkaline protease from seawater haloalkaliphilic bacteria. Process Biochem. 2014;49(6):955-62.

https://doi.org/10.1016/j.procbio.2014.03.014 